\title{
Korespondencja Adama Mickiewicza z Joachimem Lelewelem
}

Grzegorz Szelwach 


\section{Grzegorz Szelwach}

\section{Korespondencja Adama Mickiewicza z Joachimem Lelewelem}

1.

T isty Mickiewicza do Lelewela różnią się zasadniczo od listów tego pierwszego do kolegów-filomatów. Stosuje w nich inny styl zachowań towarzyskich. Zwraca się bowiem do osoby starszej, o znacznie wyższym statusie społecznym. Sytuację, w której mamy do czynienia z różnymi stylami zachowań, ilustruje przezabawny wiersz Mickiewicza Powinszowania z roku 1819, którego motyw opiera się na zabiegach o adekwatność epistologramu i osoby adresata, a ironicznie odwrócona jest znajomość konwencji:

Kiedy szlesz bilet bogatym,

Niechaj ma brzegi złocone,

Fircyka obdarz pstrokatym,

A różowym mądrą żonę.

Mogiłę albo gromnicę

Niechaj mają baby stare,

Zdrajca kraju - szubienicę,

Kokiet - kupidynków parę.

Aniołeczek dla dewotki,

Pijakowi flasza spora,

Oszustom figlarne kotki,

A śmierć maluj dla doktora.

$\mathrm{Na}$ szmacie gazety wreszcie

Poszlij życzenia gadule, 
Jurystom na manifeście,

A skąpemu na bibule.

Dla przyjaciół posyłaj na prostym papierze,

Byle szczerze ${ }^{1}$.

Utwór ten mówi wiele o Mickiewiczu — epistolografie, który to staje się w nim „arbitrem", stojącym między obowiązującymi konwencjami, występującymi w danej epoce, a prawem poety do swobody twórczej, poety świadomego odmienności stylu, w jakim należy się zwracać do różnych osób. Podobnym wierszem są Zaloty z 1825 roku. Podobnie jak Pouinszowania zachowują one tę samą strofikę, mają podobną formę dialogu, jak też można spotkać w nich żartobliwie - ironiczną postawę autora. W podobnym duchu potraktował w nim poeta relacje: nadawca — odbiorca, ciągle mając w świadomości różnice w konstrukcjach wypowiedzi występujących tam osób oraz różnorodność konwencji.

Pierwszy list $z$ listopada 1818 roku $^{2}$ pisze Mickiewicz jeszcze jako student czwartego roku. Ma wtedy dwadzieścia lat, jest autorem Zimy miejskiej, kilku klasycyzujących poematów i dopiero wstępuje w życie. Lelewel ma lat trzydzieści dwa, jest profesorem Uniwersytetu Warszawskiego (dokąd się właśnie przeniósł z Wileńskiego) i autorem prac takich, jak Dzieje starożytne, Historyka, O potrzebie gruntounej znajomości historii i Jakim ma być historyk. W tym pierwszym liście Mickiewicz zwracał się do Lelewela o pomoc w sprawie wydrukowania recenzji poematu Jagiellonida Dyzmy Bończy Tomaszewskiego na łamach „Pamiętnika Warszawskiego". List zaczyna się słowami:

\footnotetext{
' A. Mickiewicz, Dzieła. Pod. red. M. Kridla, z przedmową T. Boya-Żeleńskiego, Warszawa 1929, t. I, s. 39-40. W owym wydaniu Kridl chciał „dać możliwie pełny obraz jego twórczości”. To w założeniu popularne wydanie Mickiewicza miało być przeznaczone dla szerokich mas. Wydawca w słowie wstępnym pisał na s. 5: „Wejdzie tu więc, obok utworów poety, ogloszonych za życia, a więc mających pełną jego aprobatę, również wiele pism, zaczerpniętych z puścizny pośmiertnej. $Z$ tego dział opuszczamy tylko to, co ma wyraźny charakter rzeczy do druku nie przeznaczonych, albo przeszło do nas w stanie ułamkowym, szkicowym, nieopracowanym ostatecznie, co wymagałoby $z$ naszej strony rekonstrukcji, do których nie czujemy się uprawnieni. [...] Wyłączamy [...] natomiast wszystko, co ma charakter nieautentyczny, wszelkie utwory przypisywane tylko Mickiewiczowi". Zatem wiersz Powinszowania też został uznany przez wydawcę za autentyk, co wielu następnych wydawców kwestionowało. Za wiersz autentyczny uznal go wcześniej Gabriel Korbut w notatce O utu'orach Mickiewicza pośmiernych, „Głos” 1898, nr 35, s. 1249. Z faktem autentyczności tego wiersza liczyła się także Stefania Skwarczyńska, przywołując go w studium: Wokót teorii listu. Paradoksy, „Pamiętnikarstwo Polskie” 1972, z. 4, s. 38, jako exemplum informacji o adresacie i stosunku autora do niego. Czesław Zgorzelski opracowując Dzieła wszystkie Adama Mickiewicza, pod red. K. Górskiego, t. I, czy. IV, Wiersze, uzupełnienia i materialy, Wrocław 1987, zaklasyfikował ten wiersz do przypisywanych Mickiewiczowi z mniejszym lub większym stopniem prawdopodobieństwa ich autentyczności, s. 24. W tymże tomie na s. 68 Zgorzelski pisał: „Wierszyk przypisany został poecie przez syna, Władysława, który tekstjego włączył do utworów Mickiewicza [...] pt. Impromptu powinnzowvania, bez jakichkolwiek powątpiewań o jego autentyczności; do tytułu oddał wydawca lakoniczny przypisek: «Z autografu, oryginał nie ma żadnego tytułu. Te wiersze są z r. 1819m. Autografu jednak nie znamy; być może Władysław Mickiewicz określit tak kopię nieznanej ręki przechowywaną w Muzeum Mickiewicza w Paryżu”.

2 Do Joachima Lelewela, Wilno, 9/21 XI 1818, s. 16.

Wszystkie cytaty z listów Adama Mickiewicza pochodzą z Wydania Jubileuszowego Dziel, pod red. J. Krzyżanowskiego, t. XIV, XV, Listy, Warszawa 1955.
} 
„Wielmożny Mości Dobrodzieju!

Z imienia tylko znajomy WPanu Dobrodziejowi, ale uczeń słuchający niegdyś lekcyj jego w Uniwersytecic Wileńskim, nigdy bym się nie odważył udawać z prośbami moimi, gdyby mnie nie ośmielała dobroć WPana Dobrodzieja i nie zmuszały okoliczności”3.

Z czego można wysnuć wniosek, żc w czasie studiów spotykali się, rozmawiali, skoro Lelewel miał okazję okazać życzliwą „dobroć”.

Poeta skarżył się jednocześnie na zignorowanie jego pracy w wileńskim świecie literackim. Ów list nadawca podpisał: „WWMM-go Pana Dobrodzieja najniższy sługa i obowiązany uczeń”.

Niebawem Lelewel odpowiedziai Mickiewiczowi, informując, iż redaktor „Pamiętnika Warszawskicgo" Feliks Bentkowski przychylnie ocenił recenzję i zamierza ją wydać. List ten kończy się słowami: „O tym [...] śpieszę się donieść wielmożnemu panu, czyniąc nadzieję, że praca jego znajdzic miejsce w «Pamiętniku», co życzyłbym. Ja zaś będę szczęśliwy, że stając się pośrednikiem pisma pańskiego, potrafiłem jego żądanie uskutecznić prędkim dokonaniem danych mnie poruczeń" 4 .

Kolejny list z 24 sierpnia 1822 roku pisze Mickicwicz, który ma już w swym dorobku Ballady i romanse oraz wicrsz Do Joachima Lelewela. Tekst listu może świadczyć o niejakiej zażyłości, a przede wszystkim opiece, jaką Lelewel roztaczał nad swoim byłym uczniem, o trosce o jego dalsze losy. Poeta już jako nauczyciel kowieński martwił się ogromnie z powodu trudności z otrzymaniem paszportu. Ów list mówi nam o planach i zamiarach poety na przyszłość, o pragnieniach nic tylko możliwych i zrealizowanych. Mickiewicz np. chciał udać się do Krzemieńca, aby objąć posadę po ks. Alojzym Osińskim, bracie Ludwika, filologu i słownikarzu, profesorze literatury polskiej w Liceum Krzemienieckim w latach 1806-1824. A świadczy to o tym, jak wysoko poeta mierzył. Dalej poeta prosi swego dawnego nauczyciela, żeby dowiedzieć się „raczył”, czy jest „podobieństwo, iż katedra polskiej literatury uwolniona zostanie. Jeśliby się tak zdarzyło, mógłbym bardzo łatwo z Kowna być przeniesiony”.

Podobnym świadectwem opieki byłego nauczyciela nad byłym uczniem jest list Mickiewicza z 31 maja 1823 roku, w którym prosił Lelewela o poradę w sprawie starań o paszport zagraniczny. Nie był to już wtedy ten sam Mickiewicz, był wówczas autorem dwóch tomów Poezji, nic więc dziwnego, iz dystans między korespondującymi malał. Poeta pytał wprost: „Czy mam podać prośbę do rządu miejscowego? czy do Uniwersytetu, albo wprost do kuratora? W Pan Dobrodziej widzisz tam bliżej okoliczności; poradź mnie gdzie uderzyć"6. Tegoż samego dnia w liście do Czeczota nazwal poeta Lelewela wręcz po imieniu: „Piszę teraz do Joachima. Oddaj mu list”. A to dowodzi, iż tak o swym profesorze mówiono.

Już ta wczesna korespondencja świadczy o tym, że Lelewel troszczył się o los Mickiewicza. Starał się dlań o posadę, o paszport. Z uwielbianego profesora stawał się przyjacielem

\footnotetext{
${ }^{3}$ Ibid.

${ }^{4}$ Joachim Lelewel do Adama Mickiewicza, XI 1818, Korespondencja Adama Mickiewicza, t. III, Paryż 1876, s. 277.

5 Do Joachima Lelewela, Wilno, 24 VIII/5 IX 1822, s. 184-185.

${ }^{6}$ Do Joachima Lelewela, Kowno, 31 V/12 VI 1823, s. 246-247.
} 
i opiekunem, który wierzył w talent Mickiewicza, skoro obchodziły go jego komplikujące się losy. Wszak list z 24 sierpnia 1822 roku, kiedy to Mickiewicz starał się o posadę w Krzemieńcu i o wyjazd za granicę, poeta pisał w okresie gorącej miłości do Maryli. Było to — jak sądzę pragnienie ucieczki ze znienawidzonych stron. A może trochę - podrażniona ambicja i wynikająca $z$ tego chęć podwyższenia swego statusu społecznego ${ }^{7}$. W każdym razie jednoczesność listów do Malewskiego z 15/27 czerwca 1822 roku, czy do Zana z 16/28 września: o miłości do Maryli ze staraniami o wyjazd mówi nam, że sylwetka psychologiczna młodegc Mickiewicza daleka była od prostoty.

Obydwaj korespondenci spotykali się. 15 października Mickiewicz był na obiedziє u Lelewela ${ }^{8}$. Poeta w tym czasie krótko przebywał w Wilnie i wtedy to prawdopodobnic odebrał przywiezione trzysta rubli zaległej pensji nauczycielskiej od ówczesnego kuratora księcia Adama Czartoryskiego.

Takie obiadowe spotkania u Lelewela miały głębszy sens. Mickiewicz, Czeczot i inn filomaci - jego byli studenci, gromadząc się u niego, widzieli w nim swego ewentualnegc przywódcę, spodziewając się jego doradczego głosu.

Joachim Lelewel w tym czasie miał dla Adama Mickiewicza jeszcze inną rolę. W liściє z 30 stycznia 1823 roku pisał poeta do Zana: „Rękopism Dziadów daj Czeczotowi i powiedz niech przepisze, jak są, i odda Lelewelowi; potem obaczymy, co trzeba będzie poprawić"9.

Cóż to znaczy? Lelewel, kiedy w roku 1822 został profesorem Uniwersytetu Wileńskiegc i objął katedrę historii, został postawiony w przymusowej sytuacji i nie mógł się nie zgodzić Musiał zostać cenzorem. Pełnił te funkcję do końca swej profesury - tj. do lipca 1824 roku Podpisal miedzy innymi do druku drugi tom Poezji Mickiewicza, zawierający IV częśs Dziadów ${ }^{10}$, polecając opuścić tzw. „strofę pocałunkową”, a w Upiorze strofkę mówiącą o „zba. wienia jedynym środku"11.

\footnotetext{
7 Do Jana Czeczota, Kowno, 31 V/12 VI 1823, s. 245.

${ }^{8}$ Informacje te czerpię z Kroniki życia i twoórczości Adama Mickiewicza, 1.1798-1824, oprac. M. Dernałowicz, K Kostenicz, Z. Makowiecka, Warszawa 1957, s. 357-358: „15/27 października [...] «Nie wiedząc, nadarzył im siı poeta balladysta Mickiewicz, tego ściągnąłem do siebie na obiadową godzinę. A (...) on krótko w Wilnie bawil in: wylocie byl», Lelewel, Listy, I, 377. O tej wizycie u Lelewela pisał Mickiewicz do Jeżowskiego w niedochowanyn liście z 18/30 X [1822], Jeżowski bowiem odpisal: «Byłem i ja na obiedzie u Lelewela. (...) Czy rozmowa z tob: nie miała jakiej wagi?» Jeżowski do Mickiewicza, 2/14XI 1822, Korespondencja Filomatów, IV, 325. Być może, tego: dnia odebrał Mickiewicz przywiezione przez Joachima Joachima Lelewela 300 rubli od ks. Adama Czartoryskiego o których mu pisał Czeczot (zob.: 29 IX/11 X i 20 XI/2 XII, List do Franciszka Malewskiego).

${ }^{9}$ Do Tomasza Zana, Kowno, 30 I/11 II 1823, s. 215-216.

${ }^{10}$ Cenzorską działalność Joachima Lelewela szczegółowo opisuje J. Maciejewski w studium: $O$ „Dziadach [w:] Trzy szkice romantyczne, Poznań 1967: „Potrzeba było obrać następcę księdza Kłagiewicza [pojego śmierci], a ż nikt $z$ profesorów nie chciał przyjąć tej funkcji, (...) Andrzej Śniadecki wniósł na posiedzeniu uniwersyteckim aby (..) ktokolwiek zostanie wybrany, nie wymawiał się tego obowiązku. Przyjęto wniosek i obrany został (... Lelewel. (...) Wybranie Lelewela przyjęli filomaci entuzjastycznie" (s. 105). W tejże pracy Maciejewski zwrac uwagę na pozytywny aspekt tej sprawy: „(...) Paradoksalna sytuacja! Z cenzuralnych obostrzeń i represji wyłonił się warunki dla Mickiewicza korzystne. Mógł teraz bowiem pomyśleć i wydaniu Dziadów w tomie II Poezji Z Lelewelem na stanowisku cenzora można było rozmawiać, gdyż miał on odwagę śmiałej decyzji” (s. 106).
} 
Mickiewicz był zrozpaczony wyrzuceniem „strofy pocałunkowej”. Uważał, że niszczy to istotę dzieła. „Mimo to [...] w żadnym z następnych wydań jej nie przywrócił — a nie są to wiersze, które mu mogły wypaść z pamięci”"12.

W marcu 1823 roku poeta pisał do Czeczota: „Strofę pocałunkową, lubo najpiękniejszą, wyrzućcic, jeśli potrzeba; gdybym miał co zamiast Dziadów umieścić albo gdyby nie przymuszała do druku prenumerata, nie puściłbym tego i tak ułomnego dziecka z wyłupionym okiem"13 , a kilka dni później żalił się temu samemu: „Pozwoliłem wyrzucić owe porównanie całunku, jak się pozwala oko wyłupić, aby głowę ocalić” ${ }^{14}$. Dlaczego Mickiewicz tej strofy $\mathrm{w}$ wydaniach następnych nie przywrócił? Czy przyczyną było to, że liczył się ze zdaniem Lelewela? Jeśli - to jedną z przyczyn. Inne - to jego słynne niedbalstwo w kwestiach korekt, druku? Inne - być może - niechęć do poprawiania dawnych dzieł? A może zmienił zdanie? Jednak ta milcząca decyzja - nieprzywrócenia strofy, do której kiedyś przywiązywał ogromną wagę - pozostaje jedną z zagadek i tajemnic...

\section{2.}

Kiedy w procesie młodzieży filareckiej Mickiewicz osadzony został w areszcie 19 kwietnia 1824 roku, Lelewel znów okazał się jego opiekunem. Złożył on podanie o uwolnienie Mickiewicza i osobiście poręczył za niego "swoją osobą i majątkiem” "15, skutkiem czego 21 kwietnia tegoż roku poeta został zwolniony z więzienia.

"J. Maciejewski, ibid., poz. 12, omawia tę kwestię na s. 136. Problem Lelewelowskiej cenzury w IV części Dziadów omawia też Konrad Górski, Mickiewicz-Lelewvel, Torun 1986, s. 10: „W swoich wątpliwościach Lelewel kierowal się nie względami czysto literackimi, lecz naciskiem administracji w sprawach cenzury (...) Chodziło o jedyną strofę w wierszu Upiór i o strofę pocałunkową. Upiór został napisany, aby zastąpić I część Dziadóu', [zwłaszcza scenę] poznania się Dziewicy i Gustawa na obrzędzie dziadów. (...) Były w pierwotnym tekście Upiora dwa wiersze:

«Lecz do zbawienia ten środek jedyny.

Taka zrządzeniem najwyższym pokuta».

$\mathrm{Z}$ czego wynikało, że drogą do zbawienia jest popełnianie co roku samobójstwa. Lelewel zwrócił uwagę, że może to wywołać zastrzeżenia teologów. (...) Drugim postulatem było wyrzucenie strofy pocałunkowej. Na poprawienie tekstu Upiora Mickiewicz łatwo się zgodził".

12 Zob. M. Piwińska, Mitość romantyczna, Warszawa 1984, s. 566. Tam: interpretacja roli i dziejów „strofy pocałunkowej" (s. 565-568).

${ }^{13}$ Do Jana Czeczota, Kowno, 19 IL/III 1823, s. 222.

${ }^{14}$ Do Jana Czeczota, Kowno 26 II/10 III 1823, s. 223.

${ }_{15}$ Pisze o tym K. Górski w rozprawie: Mickiewicz - Lelewel, Torun 1986, s. 11. Nb. J. M. Rymkiewicz w Bakecie (Londyn 1989) zupełnie pomija udział Lelewela w wydostaniu poety z więzienia. Niechęć Rymkiewicza do Lelewela ujawniła się w tej książce w miejscu (s. 55) gdzie autor sugeruje, iż patriotyczne wiersze Jankowskiego Lelewel uznal za „brudne”. Nie ma na to dowodów, a prawdopodobieństwo jest niewielkie. Można natomiast przypuszczać, że obok wierszy patriotycznych Jankowski pisał inne dla własnej satysfakcji i że o tych wyrażał swój sąd Lelewel. Sprawę mogtyby rozwikłać jedynie dokumenty sądowe. Bez takich, jednoznacznych dowodów oskarżenie rzucane na Lelewela jest co najmniej niesprawiedliwe. Jego patriotyzm był powszechnie znany, jego zaangażowanie w proces poświadcza broszura Nowosilcow w' Wilnie, a jego sympatie — osobiste poręczenie za Mickiewicza. Jan Jankowski natomiast wydał swych kolegów, złożył zeznania, które spowodowały falę aresztowań. 
Pierwszy list z okresu rosyjskiego wysłał Mickiewicz Lelewelowi z Moskwy 7 stycznia 1827 roku. Był on relacją poety z podróży na Krym. Mowa tam o wielkich przeżyciach, jakie wywarły na nim krajobrazy Krymu. W żadnych innych listach z tego okresu nie ma tak szczegółowych opisów podróży, jak w owym do Lelewela — jego profesora — opiekuna przyjaciela. Jest w nim miejsce na zwięzłą informację, w której to zdanie wykrzyknikowe wyraża wielkość przeżycia poety. Jest tam też ważna wiadomość o tym, jak podróż Mickiewicza zainspirowała cykl Sonetów: „W Odessie prowadziło się życie orientalne, a po prostu mówiąc próżniackie. Ale widziałem Krym! Przetrzymałem tęgą burzę morską i byłem jednym z kilku zdrowych, którzy zachowali dosyć siły i przytomności, aby napatrzeć się do woli temu ciekawemu widowisku. (...) Widziałem Wschód w miniaturze" ${ }^{16}$.

Zwłaszcza to ostatnie zdanie przywoływane jest najczęściej przez historyków literatury. Poeta donosił w tymże liście, że jego wrażenia z podróży znajdą odbicie w Sonetach, które wysłał już historykowi i oczekuje jego zdania na ich temat. Informował też, iż kończy pisanie Konrada Wallenroda i chce napisać o Barbarze Radziwiłłównie. Pragnie zdobyć dzieła Macieja Stryjkowskiego oraz książki historyczne, źródłowe o rodzinach magnackich w wieku XVI, prosząc Lelewela o fachową pomoc i poradę.

Mickiewicz wspominał też o Lelewelu w listach do przyjaciół filomatów: „Zmiłuj się prosił Odyńca, zaniepokojony z powodu długiego nieodpisywania profesora - zapytaj Joachima, czy on także mój list długi, jeszcze w styczniu na Petersburg wysłany, odebrał i czy będzie łaskaw mnie odpisać?”17. Tamże zasygnalizował poeta potrzebę posiadania miniaturowych portrecików Lelewela, Odyńca, Niemcewicza, Zaleskiego i Brodzińskiego. Miały mu one, przebywającemu na obczyźnie, przypominać ojczyznę i pozostawionych tam przyjaciól.

Lelewel w odpowiedzi na styczniowy list Mickiewicza udzielonej 26 kwietnia 1827 ro$\mathrm{ku}^{18}$ radził sięgnąć po kronikę Orzechowskigo, aby uzyskać informacje o Barbarze Radziwiłłównie, jednocześnie stwierdzając, że starania o inne książki i broszury są zbyteczne, gdyż po prostu ich nie ma. Historyk dobrze też oceniał zadowolenie poety z podróży na Krym, że znalazł w niej satysfakcję. Przesłał także wszystkie drukowane opinie o Sonetach, których krytycy chwalący dawniej ballady i Dziady zdaniem Lelewela nie zrozumieli i nie ocenili tak, jak naprawdę należało je wysoko ocenić. Ponadto list zawiera informacje o działalności warszawskiego Towarzystwa Przyjaciół Nauk i o krytycznoliterackich pracach Juliana Ursyna Niemcewicza, Kazimierza Brodzińskiego i Franciszka Salezego Dmochowskiego. Autor listu wzmiankuje również o literackich nowościach Warszawy i Poznania.

Znamienne jest, iż o projekcie (nigdy nie zrealizowanym) pisania dramatu o Barbarze Radziwiłłównie nie pisał Mickiewicz w żadnym innym liście z tego okresu. Dowodzi to, iz Lelewel był nie tylko wielkim autorytetem dla poety, ale i powiernikiem, skoro zwierzał się

${ }^{16}$ Do Joachima Lelewela, Moskwa 7/19 I. 1827, s. 323-324.

17 Do Antoniego Edwarda Odyńca, Moskwa, 14 IV. 1827, s. 338.

${ }^{18}$ Lelewel do Mickiewicza, 26 IV 1827, Korespondencja Adama Mickiewicza, t. II, Paryż 1872, s. 39-41. 
mu z tak śmiałego projektu pisarskiego, bo już wcześniej zrealizowanego przez Franciszka Wężyka i Alojzego Felińskiego.

W liście z sierpnia tegoż roku dziękował Mickiewicz Lelewelowi za jego uwagi o Sonetach. Pisał tamże o języku własnej poezji, o świadomie popełnionych błędach gramatycznych („kołysa” zamiast „kołysze”, „klaska” zamiast „klaszcze”). Dalej tak żartobliwie poeta komentuje owo zjawisko: „Może się potem poprawię, ale dotąd muszę swojego ucha radzić się i jemu zaufać" ${ }^{19}$ i dodaje: "gdybym sam na siebie recenzją pisał, byłaby najsurowsza”20.

Ów list jest bardzo osobisty. Mickiewicz do niewielu osób tak pisał, nielicznych traktował tak poważnie jak Lelewela.

Ten ostatni pojawia się znów w korespondencji Mickiewicza z Odyńcem w maju 1828 roku. Skarżył się tam poeta na plotki, jakie powstały wokół jego osoby w związku z podobizną wykonaną przez Lelewela: „W Warszawie wylitografowaliście ze mnie małpę. Ktoś fałszywie doniósł, że bardzo za to się zagniewałem i że paryski portret podarłem. Fałsz wielki. Portret paryski dosyć kształtny; podarto go, przesyłając, a ja nawet karykatury z rąk p. Joachima otrzymanej nie śmiałbym źle traktować. P. Joachim takim i podobnym wieściom niech nie wierzy" ${ }^{21}$. Kolejny raz imię Lelewela wymieniane jest w liście Mickiewicza do Odyńca z lipca 1828 roku. Prosił w nim poeta Odyńca o portret zaznaczając, iż "Joachima już ma”.22. Portrety przyjaciół przechowywał Mickiewicz przez całe swoje życie ${ }^{23}$.

W liście z końca lipca 1828 roku $^{24}$ poeta radzil się historyka w sprawach politycznych, towarzyskich i edytorskich. Na wstępie wspominał o liście z zimy 1827 roku, który zaginął, Mickiewicz prosił w nim o „rady różne”.

Następnie wspomimał o edycji Poezji i Konrada Wallenroda w Paryżu, Poznaniu i Lwowie. Sformułował bardzo ostrożne uwagi o twórczości Lelewela. Podziwiał jego talent naukowy, ale z drugiej strony pisal: „Szkoda tylko, że dla uczonych badań zdajesz się opuszczać właściwą historię"25. Dalej Mickiewicz tłumaczył się jeszcze jak uczeń z powodu dawania rad swojemu mistrzowi. A w końcowej partii listu prosił Lelewela o nazywanie siebie po imieniu, co miałoby ułatwić kontakt korespondencyjny.

Lelewel odpowiedział Mickiewiczowi 17 listopada tegoż roku ${ }^{26}$. We wstępie omawia sprawy edycji utworów poety w Paryżu i w Poznaniu. Z kolei informuje poetę, iż pieniądze

${ }^{19}$ Do Joachima Lelewela, Moskwa, 7/19 VIII. 1827, s. 346.

${ }^{20} \mathrm{Ibid}$.

${ }^{21}$ Do Antoniego Edwarda Odyńca, Petersburg, 20 V/1 VI. 1828, s. 395.

22 Do Antoniego Edwarda Odyńca, Petersburg, pocz. VII. 1828, s. 399.

${ }^{23}$ Obecnie miniaturowe portrety: Kazimierza Brodzińskiego, Juliana Ursyna Niemcewicza i Józefa Bohdana

Zaleskiego znajdują się w Dziale Grafiki Muzeum Literatury im. Adama Mickiewicza w Warszawie.

${ }^{24}$ Do Joachima Lelewela, Petersburg, koniec VII. 1828, s. 405-408.

${ }^{25}$ Ibid.

${ }^{26}$ List Lelewela do Mickiewicza, pisany 17 XI 1828, Korespondencja Adama Mickiewicza, t. III, Paryż 1876, s. 138-142 (z błędnie podanym tamże rokiem 1830). 
za edycję Konrada Wallenroda wypłaci prokurator Kajsarow ${ }^{27}$. Następnie profesor polemizuje $\mathrm{z}$ poetą $\mathrm{w}$ sprawie interpretacji swoich pism historycznych, zwłaszcza Poczq̨tków polskiego prawodaustwa. Spiera się ze zdaniem o odrywaniu się od tworzenia tej właściwej historii na rzecz badań specjalistycznych. Mickiewiczowi chodziło o to, żeby Lelewel uprawiał historię ogólną, a nie wciągał się w pracochłonne i żmudne (a nieco - jego zdaniem — marginesowe) badania nad historią prawa, numizmatyką itp. Inaczej mówiąc - Mickiewicz oczekiwał po nim nowej syntezy, Lelewela zaś pasjonowały nauki pomocnicze historii, badał konkrety, lubił rzetelną robotę. Ponadto, jak sądzę, Lelewel nigdy by nie wygłosił prelekcji paryskich, które swobodnie żonglują faktami, dają ogromne syntezy...

Ale Lelewel zaznacza, iż dzieło jego o prawodawstwie jest poczytne, zwłaszcza wśród młodych prawników. Spotkało się ono z wieloma recenzjami.

Z kolei informuje on Mickiewicza o zamiarze pisania historii wieków średnich, o swoim pragnieniu wydania Dziejów Polski potocznym napisanych sposobem, dla użytku dzieci i wszelkiego stanu ludzi. Prosił Mickiewicza o pośredniczenie w wydaniu w Petersburgu swego Obrazu dziejów Polskich oraz o pomoc w sprzedaży w tym mieście pewnej ilości egzemplarzy Dziejów bibliotek. Na koniec prosi: „Przypomnij mię, Adamie, wszystkim znajomym. A sam trzymaj mię w sercu twojem” - i podpisuje się jako „szczerze życzliwy i kochający sługa” ${ }^{28}$. Te słowa, jak i cały list są świadectwem zmniejszenia dystansu między korespondującymi.

Kolejnym tego dowodem jest list z 5 grudnia 1828 roku$^{29}$. Mickiewicz - co prawda na wstępie tłumaczył sic̨ ze swoich opinii z listu poprzedniego na temat odbioru przez czytelników dzicła o prawodawstwic, co jest jeszcze bardzo „studenckie”. Dalej jednak następują swobodne relacje poety z aktualnego stanu własnej twórczości oraz uwagi o staraniach, jakie czynił przy wydaniu Dziejów Polski Lelewela. Zwłaszcza ten ostatni fakt dowodzi tego, że Mickiewicz jak równorzędny partner zajmował się wydawaniem dzieła swego dawnego nauczyciela. Zaś w liście z 16 stycznia 1829 roku, Mickiewicz już na wstępie pozwolił sobie na elegancki żart: "Chociaż przebaczasz mnie wszelkie kłopoty i komisa, którymi ciebie obarczam, czuję zawsze zgryzotę sumienia i lękam się, aby Klio, albo inna jaka muza sprawująca obowiązki patronki bibliografii i bibliotek, nie zemściła się na mojej muzie za te księgarskie i wekslarskie narzucane tobie roboty, mój szanowny mistrzu i przyjacielu” ${ }^{\text {”30 }}$.

W tym liście wspomina poeta o swojej rozprawic O krytykach i recenzentach warszawskich ${ }^{31}$. Miała ona być w zamierzeniu autora zaledwie początkiem wielkiej walki z klasycyzującymi

${ }^{27}$ W Wydaniu Jubileuszowym Dziel Mickiewicza, t. XIV, s. 439 jest informacja, że na odwrocie listu Mickiewicza do Joachima Lelewela, Petersburg, 5/17 XII. 1828 znajduje się dłuższy przypisek Franciszka Malewskiego, a w nim ustęp: „Adma zapomniał napisać, że mu Kajsarow 600 rubli zapłacił, ale go w oczy nie widział, bo ten pan zdawal się go tu teraz unikać".

${ }^{28}$ Ibid., poz. 12, s. 141-142.

${ }^{29}$ Do Joachima Lelewela, Petersburg, 5/17 XII. 1828, s. 436-438.

${ }^{30}$ Do Joachima Lelewela, Petersburg 16/28 I. 1829, s. 451.

${ }^{31}$ Rozprawa O krytykach i recenzentach warszawskich Adama Mickiewicza jest pamfletem na warszawskie środowisko literackie, na jego zacofanie, ciasnotę horyzontów, stagnację umysłową oraz duze opóźnienie w stosunku do myśli zachodnioeuropejskiej. Mickiewicz warszawską krytykę potępił w czambuł, nie czyniąc 
krytykami literackimi. Mickiewicz sam trochę uważał siebie za krytyka, naturalnic nowocześniejszego od klasycznych, bo romantycznego. I dlatego też, gdyby nie powstanie listopadowe, można by sobie wyobrazić inaczej rozwój intelektualny Mickiewicza. Poeta wspominał o projekcie wydawania w Rosji pisma literackiego, które miałoby być nowocześnie redagowanym organem romantyzmu: „(...) Zacznę pisać różne literackie rozprawy. (...) Mam wielkie dla talentu poszanowanie, i autorowie, klasa, że tak powiem, plodna w literaturze, zasługują na słuszne względy i na pobłażanie nawet uchybieniom"32. Plany te nigdy nie zostały zrealizowane z powodu surowych działań aparatu carskiej cenzury. Wypada mi w tym miejscu też wspomnieć, iż rozprawa Do krytyków..., napisana jako przedmowa do petersburskiej edycji Poezji, nie spodobała się zapewne historykowi, gdyż nie wspominał o niej w żadnym z listów do Mickiewicza, mimo że ten wielokrotnie prosił.

W tym samym liście ze stycznia 1829 roku pisał poeta o Lelewelowej recenzji dzieła Mikołaja Karamzina Historia państwa rosyjskiego ${ }^{33}$. W owym czasie były nadzieje na jej drukowanie, a przerwanie druku przypisywał Mickiewicz profesorowi Józefowi Sękowskiemu, przed kontaktami z którym ostrzegał Lelewela ${ }^{34}$.

wyróżnień, nie doceniając Maurycego Mochnackiego. Ta niesprawiedliwość wywołana została być może irytacją z powodu płaskiej i głupiej krytyki Sonetów przez Warszawian w Bibliotece Polskiej, przede wszystkim zaś - Franciszka Salezego Dmochowskiego. Innym powodem irytacji może być dystans dzielący Petersburg (gdzie powstała rozprawa) od odległej Warszawy.

${ }^{32}$ Ibid., poz. 16, s. 452.

${ }^{33}$ Dzieło to zajmowało szczególnie B. Galstera w książce: Paralele romantyczne. Polsko-rosyjskie powinowactw'a literackie, Warszawa 1987. Autor zauważa, iż Lelewelowska krytyka Historii Karamzina została napisana nie z pobudek naukowych, lecz z przyczyn czysto politycznych. Lelewel porównywał tam Mikolaja Karamzina do Adama Naruszewicza, co nie mogło nie rozdrażnić carskiej cenzury. Stąd też wynikały niecne zabiegi Sękowskiego o to, aby recenzja nie została wydana w Rosji (s. 29-40). Lelewel miał do Karamzina wiele szacunku jako do „dostojnego męża” rosyjskiego, wielkiego historiografa państwa, tytanicznie pracującego nad historią Rosji (s. 41). Ogólne uwagi o Historii rozpoczyna Lelewel do uwag nad stosunkiem Karamzina do historii starożytnej. Broni nie docenianych przez niego myślicieli greckich i rzymskich: Tucydydesa, Herodota i Liwiusza. Polski historyk sprzeciwia się rówież porównywaniu hisotrii Grecji z dziejami Rusi. Podkreśla rolę walki o zasady ustrojowe między systemami arystokratycznym i demokratycznym (s. 43-44). Sens polityczny widać w porównaniu narodowego charakteru dziejów Karamzina i Naruszewicza (s. 45). Lelewel jest też zgodny z Karamzinem w ocenie podbojów ludów normańskich - jako nosicieli kultury (s. 45). Galster wskazuje także na istotne znaczenie nauk Karamzina i Lelewela dla Mickiewicza: „Uczeń Lelewela przyswoił sobie od mistrza umiejętność posługiwania się nowoczesnymi pojęciami historycznymi, zawdzięczał mu też niejedno twiedzenie szczegółowe, wyzyskane $w$ dalszej przyszłości w wykładach literatury słowiańskiej. W najbliższej zaś perspektywie czasowej przejęcie się ideami Lelewela o sposobie pisania historii i o początkach państwa ruskiego mołgo ułatwić - i chyba ułatwiło — zesłanemu poecie intelektualne i ideowe porozumienie z postępowymi kołami rosyjskimi" (s. 29).

${ }^{34}$ W tym miejscu wypada podać informacje o Józefie Julianie Sękowskim (1800-1858): „Początkowe nauki pobierał pod kierunkiem matki oraz wuja, profesora G. E. Grodka. Po krótkim pobycie w kolegium mińskim wstąpił na Uniwersytet Wileński na wydzial filozoficzny. Pod wpływem Grodka i Joachima Lelewela zająl się badaniem Wschodu. Należal do Towarzystwa Szubrawców i był współpracownikiem, Wiadomości Brukowych". W 1819 (...) wyruszył w dwuletnią podróż na Wschód. W 1820 był dragomanem misji rosyjskiej w Konstantynopolu. (...) W Petersburgu (...) został thumaczem w ministerstwie spraw zagranicznych. W 1822 otrzymał nominację na profesora języków wschodnich (jęz. arabski) nie uniwersytecie w Petersburgu. Ofiarowanej mu przez Uniwersytet Wileński katedry języków wschodnich nie przyjął. W 1823 został 
Z kolei Mickiewicz donosił Lelewelowi o wydaniu w Petersburgu drugiego tomu swoich Poezji, którymi to „zajął jedynie tu dobrą drukarnie polską" ${ }^{35}$. Na samym końcu listu prosił poeta o wiadomości o warszawskich pracach krytyków literackich.

Nie doczekał się jednak odpowiedzi w tej kwestii w niezmiernie krótkim liście Lelewela z 5 lutego $1829^{36}$. Nie było tam ani slowa o Mickiewiczowskiej Przedmowie. Historyk skarżył się na brak czasu, a jego list miał właściwie charakter urzędowy.

Zgodnie z wcześniejszą zapowiedzią Lelewel przesłał kilka egzemplarzy Dziejów bibliotek, które Mickiewicz miał pomóc rozprzedać w Petersburgu. List podpisany jest: „twój szczerze życzliwy przyjaciel Lelewel" 37 .

Ostatni list Mickiewicza do Lelewela z okresu rosyjskiego jest z marca 1829 roku. Informuje poeta na wstępie o przysłanych blachach, o które był proszony, z kolei zaś przechodzi do spraw mniej przyziemnych. Wysyła on pakę nowego wydania II tomu Poezji z prośbą o rozprowadzenie w księgarniach warszawskich lub też za pośrednictwem Waleriana Krasińskiego.

Mickiewicz prosił Lelewela kolejny raz o opinię o „przedmowie”, czyli o rozprawie O krytykach i recenzentach warszawskich.

W liście tym jest zaszyfrowana informacja o tym, iż poeta szykował się do wyjazdu z Rosji: „Ja wszedłem tu w służbę do Kolegium interesów zagranicznych, ale dla słabości ciągłej zdrowia nie wiem, czy tu ciągle bawić będę"38. To oczywisty szyfr, a szerzej o sprawie miał Lelewelowi w Warszawie opowiedzieć Odyniec, gdyż z oczywistych względów cenzuralnych Mickiewicz nie mógł pisać o tym wprost. Jeszcze pod koniec lutego tego roku sprawa pozwolenia na wyjazd z Rosji była już rozstrzygnięta pomyślnie.

W okresie rosyjskim Mickiewicza Lelewel był jeszcze obecny w liście do Odyńca. Poeta wiedział, iż niebawem opuści Rosję i uda się do Niemiec. Tą zaszyfrowaną informacją pragnął poprzez Odyńca podzielić się z Lelewelem: „Za kilka tygodni dla poratowania zdrowia za granicę wyjeżdżam. (...) Opowiedz to (...) tymczasem, panu Joachimowi, nim do niego oddzielnie napiszę"39. Ponieważ szykował się do wyjazdu, były mu potrzebne pieniądze od Waleriana Krasińskiego za Sonety i Konrada Wallenroda i dlatego prosił o szybką inter-

członkiem korespondentem Warszawskiego Towarzystwa Przyjaciól Nauk, w 1826 doktorem filozofii Akademii Krakowskiej, w 1828 członkiem (...) Petersburskiej Akademii Nauk. W 1825 i 1827/28 spotykal się w Petersburgu z Adamem Mickiewiczem. W 1826 został wysłany przez uniwersytet na wizytację okręgu szkolnego białoruskiego. W 1828-1833 był członkiem komitetu cenzury. (...) W 1832 zerwał całkowicie ze społeczeństwem polskim. Pod pseudonimem Barona Brambensa drukował satyry także i przeciwko Polakom. (...) Sękowski wywarł wpływ na utwory Adama Mickiewicza o tematyce orientalnej (Almotenabbi, Farys, Szanfary)" Nowy Korbut, t. 9, s. 129-130. Mickiewicz uczył się u Sękowskiego arabskiego, a jednocześnie, obcując z tym człowiekiem, musiał być ostrożny.

${ }^{35}$ Ibid., poz. 16, s. 452-453.

${ }^{36}$ List Lelewela do Mickiewicza z 5 II 1829, „Echo Polskie”, Moskwa 1916, nr 41, s. 20. Wydawca podał mylnie, że to list do Franciszka Malewskiego.

${ }^{37}$ Ibid.

${ }^{38}$ Do Joachima Lelewela, Petersburg, 6-7/18 - 19 III 1829, s. 477.

${ }^{39}$ Do Antoniego Edwarda Odyńca, Petersburg, ok. 24 IV/6 V 1829, s. 481. 
wencję Odyńca. W tymże liście ostrzegał raz jeszcze Lelewela przed Józefem Sękowskim i jego złymi zamiarami: „Jedzie podobno do Warszawy p. Sękowski, orientalista, w różnych celach, widokach, zamiarach; radzę go strzec się i mieć na oku. Znam go bardzo, bardzo, bardzo, bardzo, bardzo dobrze. Powiedz o tym panu Joachimowi” ${ }^{40}$.

\section{3.}

W czerwcu 1829 roku Mickiewicz był już w Berlinie. Pierwszy list do Lelewela po wyjeździe z Rosji miał w sobie znamiona wolności. Widać, że pisał go czlowiek, który opuścił kraj wroga po dłuższym przebywaniu w nim wbrew własnej woli. Autor listu informował, iż przepłynął Bałtyk, zwiedził Lubekę i starożytny ratusz Hansy, był kilka dni w Hamburgu, a obecnie zwiedza Berlin, skąd rusza do Drezna, Weimaru i Włoch.

Mickiewicz pragnął zapoznać Lelewela z rosyjskim poetą - Wasilijem Żukowskim, swoim serdecznym przyjacielem, którego rekomendował profesorowi jako „męża rzadkiego charakteru i rzadkiej uczciwości” ${ }^{41}$.

Żukowski miał jechać z Berlina do Warszawy.

Mickiewicz bardzo chciał, żeby się przedmowa Lelewelowi podobała. Nie stało się tak jednak. Poeta pisał: „Słyszałem, żeś nie bardzo rad z przedmowy! Cierpię nad tym” ${ }^{42}$. Opinia Lelewela doszla Mickiewicza zapewne przez Malewskiego bądź Odyńca. Natomiast w listach do Mickiewicza Lelewel o tej rozprawie konsekwentnie nie wspominał. Poetę bardzo bolało, że czlowiek, którego uważał za autorytet, który był jego przyjacielem udzielającym zawsze chętnie rad, milczał w tak ważnej dla niego sprawie.

W kolejnym liście, wysłanym jeszcze tego samego dnia ${ }^{43}$ ponownie Mickiewicz polecał poetę rosyjskiego - Żukowskiego przybywającego do Warszawy. Poecie zależało bardzo na tym, aby Żukowski przebywając w stolicy zaznajomił się z poetą Bohdanem Zaleskim. W tym, jakże krótkim i formą przypominającym urzędowy, liście informował poeta o planach wyjazdu z Berlina do Weimaru albo Drezna.

Ostatni przedpowstaniowy list Mickiewicza do Lelewela został napisany w Rzymie 6 lutego 1830 roku $^{44}$. To najbardziej osobisty list poety do dawnego nauczyciela. Można $\mathrm{z}$ niego się dowiedzieć, $w$ jakim stanie psychicznym znajdował się Mickiewicz, jak był wewnętrznie rozdarty, jak targały nim wątpliwości. Sam nie wiedział, jak ziścić nierealny projekt powrotu na Litwę, o czym pisał w zaszyfrowanych słowach: „Czekam niecierpliwie wiosny, ażeby kiedy niekiedy odświeżyć imaginacją widokiem świeżej natury” ${ }^{{ }^{45}}$. Dalej stwierdził, iż od siedmiu lat nie miał pewności, iż zabawi w jednym miejscu choćby rok,

\footnotetext{
${ }^{40}$ Ibid., s. 484.

${ }^{41}$ Do Joachima Lelewela, Berlin, 12 VI 1829, s. 492.

42 Ibid.

${ }^{43}$ Do Joachima Lelewela, Berlin, 12-13 VI 1829, s. 497.

${ }^{44}$ Do Joachima Lelewela, Rzym, 6 II 1830, s. 516.

${ }^{45}$ Ibid.
} 
a w następnym zdaniu projektował: „Gdybym kiedy osiadł nareszcie, gdybym miał pod ręką bibliotekę polską, (...) wziąłbym się naprzód za jaką epokę dziejów ojczystych" "46 . Zaś kilka linijek dalej pisze: „(...) puściłbym się dalej ku Wschodowi”47 . A więc w jednym liście są aż trzy różne projekty, coświadczy o tym, że Mickiewicz nie miał jednego projektu, jednej jasnej wizji swej przyszłości, że znajdował się na rozdrożu, i o tym pisał do Lelewela.

Następnie Mickiewicz informował o swoich zainteresowaniach rzymską historią, o propagowaniu przez siebie Lelewelowskiej Historii polskiej w środowisku emigracyjnym. Zaś przy końcu listu nawiązał kolejny raz do swojej rozprawy O krytykach i recenzentach: „À propos literatury, chciałem jeszcze raz o mojej przedmowie do ciebie napisać, ale już miejsca nie mam. Wreszcie wolę przyszłymi dziełami (jeśli się urodzą) na zarzuty odpowiedzieć” ${ }^{48}$. Była to ostatnia prośba Mickiewicza o opinię na temat tej rozprawy, Lelewel nigdy jej nie udzielił. Być może dlatego też nie odpisał na ten list. Może tu zaczynają się rozchodzić ich drogi? Milczenie historyka - to przemilczana różnica zdań, to niewypowiedziany konflikt.

Jeśli zaś chodzi o stan psychiczny Mickiewicza w tym okresie, to - zdaniem moim nie należy zbytnio wierzyć Listom z podróży Odyńca ${ }^{49}$. Choć są ważnym tekstem dla historii literatury polskiej, jednak w ich świetle obraz Mickiewicza nic wypada całkiem prawdziwie. Można by odnieść mylne wrażenie, że „Adam [to] (...) niejako (...) emblematyczny obrazek ówczesnego społeczeństwa” ${ }^{50}$, nicustannie będący w doskonałym humorze i można by powiedzieć — w natchnieniu”, palący „fajkę przy kawie (...) [zatopiony] w cnotach Romy”, lubiący „sicdzieć po turecku (...) [razem z Odyńcem] jak pijany” ${ }^{~ 52}$, czy też z „księciem Olesiem [Wodzickim] grać w szachy" 53 , oraz słuchać śpiewów księżny Zinaidy Wołkońskiej i pana Allesandro Ricci - „największego powabu (...) wieczorów” 54 teatru amatorskiego księżny.

Z Listów z podróży wyłania się obraz Mickiewicza - turysty, zajętego życiem towarzyskim, zwicdzaniem. Ale listy samego poety świadczą o innym stanie ducha. Mickiewicz już wtedy był zmęczony niepewnością swego losu i wieloletnią nieobecnością w kraju, pełen rozterek. A są to - wspomniany wcześniej — list do Lelewela z 6 lutego 1830 roku i do

\footnotetext{
46 Ibid.

47 Ibid.

${ }^{48}$ Ibid., s. 517. (zwłaszcza do Lelewela) z tego okresu.

${ }^{50}$ Ibid., poz. 9, t. II, s. 94. List Odyńca do Ignacego Chodźki, Rzym 31 XII 1829.

${ }^{51}$ Ibid., s. 110. List Odyńca do Juliana Korsaka, Rzym, 25 I 1830.

52 Ibid., s. 111. Odyniec do Korsaka, j. w., poz. 12.

53 Ibid., s. 114. Odyniec do Korsaka, j. w., poz. 12.

${ }^{54}$ Ibid., s. 124. Odyniec do Korsaka, j. w., poz. 12.
}

49 Antoniego Edwarda Odyńca Listy z podróży t. I-II, oprac. M. Toporowski, wstęp M. Dernałowicz, Warszawa 1961. Zdaję sobie sprawę, że jest to tekst niepewny, bo pisany znacznie później, po odbytej wspólnej podróży z Adamem Mickiewiczem po Europie od lipca 1829 do października 1830, ale mimo licznych nieścisłości, jest jednak tekstem ważnym, gdyż opowiada o znajomościach, przygodach i sentymentach Mickiewicza na tle zmiennej scenerii romantycznego wojażu. Pozwolę sobie czasem je konfrontować z listami Mickiewicza 
Franciszka Malewskiego z 2 lutego, tegoż roku, gdzie o swoim teraźniejszym życiu miał niewiele do powiedzenia: „tam dobrze, gdzie nas nie ma, (...) [a] pobyt w Rzymie nie tak zazdrosny, jakby się zdawało" "55. Oba obrazy Mickiewicza mogą być trafne. Widać dwie twarze poety, na zewnątrz pogodnego towarzyskiego bo też i miał sukcesy, ale jednocześnie odczuwającego on smutek emigracji.

Kolejny list Mickiewicza do Lelewela z marca 1832 roku, a więc już po powstaniu listopadowym, zaczyna się od tłumaczeń z powodu poniechania korespondencji w czasie powstania, aby mu nie przeszkadzać adresatowi w jego politycznej działalności. Mickicwicz ogromnie bolał nad tym, iz nie wziął udziału w powstaniu listopadowym. Czuł się, jak gdyby był już na sądzie ostatecznym — „na dolinie Josafatowej”, ponieważ „Bóg nie pozwolił [mu] być uczestnikiem jakimkolwiek w tak wielkim i płodnym na przyszłość dziele” ${ }^{„ 56}$.

Dlaczego Mickiewicz nie wziął udziału w powstaniu listopadowym? Pytanie to stawiało sobie wielu historyków. Nie rozważając tu ogromnej dyskusji poświęconej tej kwestii, przytaczam zdanie z najnowszej refleksji Zofii Stefanowskiej: „[Mickiewicz] sceptycznie przyjął(...) wybuch [powstania], nieufnie obserwował przebieg, nawet sukcesy, zaakceptował (...) bez zastrzeżeń w klęsce ,(..) [a ponieważ] umiał nie podzielać powstańczego entuzjazmu, zjednoczył się ze zbiorowością w rozpaczy wobec klęski”, ${ }^{\circ}$.

I tu widać dwoistość Mickiewicza: powstanie nie wzbudziło jego entuzjazmu, i właśnie dlatego czuł się podwójnie winny po klęsce, że nie wziął w nim udziału. Zdawał sobic też sprawę, że wielu rzeczy o powstaniu nie wiedział, wielu nie rozumiał, więc zwracał się do Lelewela jako do autorytetu, a także uczestnika, niemal inicjatora powstania. Bo przecież musiał się orientować, jaką w nim rolę odegrał Lelewel, i co mu zarzucano (zwłaszcza Maurycy Mochnacki). Mickiewicz nie rozumiał tych zarzutów. Prosił swego dawnego nauczyciela, aby „objaśnił (...) wiele wypadków niepojętych, [bo] nie lada czyjemu objaśnianiu wierzył” ${ }^{58}$. Ten dramatyczny list z 23 marca 1832 roku pełen jest osobistych refleksji filozoficzno-etycznych, które nadają ton listom Mickiewicza z okresu popowstaniowego. Rozczarowany co do skłóconej polskicj emigracji i do Francuzów nie rozumiejących spraw polskich pisał wprost: „Paryżem (...) brzydzę się jak pickłem"59. Mickiewicz w owym liście wskazywał na potrzcbę moralnego odrodzenia polskiego narodu i chciał, aby „na katolicyzmic (...) grunt polożyć” 60 .

W tym okresic zwrotu religijnego Mickiewicz pisał liryki rzymskie ${ }^{61}$ : Arcy-Mistrz, Rozum i wiara, oraz Rozmowa wieczorna. One to są tłem dla listu do Lelewela. Pytał w nim, czy zna

${ }^{55}$ Do Franciszka Malewskiego, Rzym, 2 II 1830, s. 512.

${ }_{56}^{56}$ Do Joachima Lelewela, Drezno, 23 III 1832, t. XV, s. 16.

${ }^{57}$ Z. Stefanowska, Geniusz poety, geniusz narodu. Mickieurizz wobec poustania listopadou'ego, „Teksty Drugie”, 1995, nr 6, s. 19-31.

${ }^{58}$ Ibid., poz. 17.

${ }^{59}$ Ibid., poz. 17.

${ }^{60} \mathrm{Ibid}$., poz. 17, s. 17.

${ }^{61}$ O drezdeńskim pochodzeniu wierszy Arcy-Mistrz, Rozum i uiara oraz Rozmou wieczorna pisał Wacław Kubacki w studium: Legenda o rzymskim pielgrzymie. gdzie kładzie nacisk na związki owych utworów z napisaną w Dreźnie trzecią częścią Dziadóu. Osobiście podobnic jak Alina Witkowska w książce: Mickieuicz. Stouo 
francuskiego pisarza religijnego i publicystę ks. Felicité-Roberta Lamennais i jego pismo „L'Avenir” (Przyszłość). Popierało ono powstanie, a i sam jego założyciel szczerze rozumiał Polaków i bolał nad upadkiem listopadowego zrywu. Mickiewicz uważał naród polski za powołany do przekazywania innym narodom „ewangelii narodowości, moralności i religii [oraz] wzgardy dla budżetów, jedynej zasady teraźniejszej polityki, prawdziwie celniczej”62.

W omawianym drezdeńskim liście wspominał poeta o swym przyjacielu poecie Stefanie Garczyńskim: „Rewolucja wydała poetę swego, nie znanego jeszcze. Jest to Garczyński. (...) Talent wielki i daleko pójdzie; już teraz jest na stanowisku, na którym ostatnie dzieła moje spoczeły"63.

Mickiewicz wspominał też o przebywającym w Dreźnie, zajmującym się tłumaczeniem Czcicieli ognia Moore'a i Korsarza Byrona Odyńcu, z którym to „siedzieli (...) samotni zupełnie, z nikim się nie wdając" ${ }^{64}$. Jest to kolejny wyraz nieufności poety do kręgów emigracyjnych na Zachodzie. Wolał on przebywać w towarzystwie człowieka, którego znał i z którym przyjaźnił się od lat i był mu bliski. W post scriptum listu projektował, aby Leonard Chodźko ułożył „Martyrologię polską”, czyli alfabetyczny katalog męczenniików narodowych od czasu konfederacji barskiej, a w ostatnim zdaniu w iście studencki sposób zapytywał swojego dawnego nauczyciela, czy należy pisać projekt „Martyrologii” w języku francuskim.

$\mathrm{Na}$ ten list, jak i na następny z maja 1832 roku Lelewel Mickiewiczowi nie odpowiedział. Miał on wtedy czterdzieści sześć lat, był znękany, osamotniony, w trudnej sytuacji osobistej i politycznej. Stracił niemal doszczętnie swój wielki autorytet, oskarżony przez Mochnackiego. Stał się zgorzkniały, zamknięty, samotny i rozgoryczony.

W majowym liście wysłanym z Drezna do Paryża prosił Mickiewicz Lelewela o pomoc w wydaniu trzeciej części Dziadów i Ustępu. Swoje dzieło poeta uważał za „kontynuację wojny, którą teraz, kiedy miecze schowane, dalej trzeba piórami prowadzić” ${ }^{65}$. A w post scriptum zwierzal się z tego, że natchnienie poetyckie nie opuszczało go: „Od czasu pisania «Dziadów» [części II i IV] nigdy nie byłem $w$ takim poetyckim ferworze i bardzo wiele teraz piszę"66.

W końcu lipca 1832 roku Mickiewicz wyjechał do Paryża, gdzie Lelewel jeszcze w grudniu 1831 roku utworzył Komitet Narodowy Polski, aby „czuwać nad interesem narodowym i nad losem wypartych z ojczyzny Polaków" ${ }^{67}$. Komitet zajmował się rozdzielaniem funduszów składkowych pośród polskich emigrantów. Starał się ich organizować i reprezentować

i czyn, Warszawa 1986, s. 106, sądzę, iż „niepodobna kłaść głowy pod ewangelię w sprawie wyłącznie drezdeńskiego pochodzenia tzw. liryków religijnych”. A przede wszystkim, jak pisze uczona: „w sferze ideologii religijnej istnieje pełna ciagłość przemyśleń Mickiewicza «rzymskiego» i «drezdeńskiego»”.

62 Ibid., poz. 17, s. 17.

${ }^{63} \mathrm{Ibid}$., poz. 17, s. 17. Mickiewicz miał na myśli Sonety wojenne Stefana Garczyńskiego, napisane w czasie powstania listopadowego. Mickiewicz uważał się za opiekuna Garczyńskiego. Był powiernikiem i przyjacielem swego młodszego kolegi-poety.

${ }^{6+}$ Ibid., poz. 17, s. 17.

${ }^{65}$ Do Joachima Lelewela, Drezno, V 1832, t. XV, s. 31.

${ }^{66}$ Ibid.

${ }^{67}$ S. Kieniewicz, Samotnik brukselski. Opowieść o Joachimie Lelewelu, Warszawa 1964, s. 11. 
ich interesy wobec rządów i opini publicznej Zachodu. Komitet popierany był przez Komitet Francusko-Polski z weteranem Wielkiej Rewolucji Francuskiej - generałem Lafayette na czele.

Mickiewicz wziął udział w pracach nad ogłoszoną w połowie grudnia 1832 przez Lelewelowski Komitet Odezwa do Rosjan, która spowodowała usunięcie na żądanie rosyjskiej ambasady Lelewela z Paryża w końcu grudnia tegoż roku. Wcześniej - 16 grudnia Mickiewicz podpisał wraz z 48 emigrantami Adres tutaczów polskich $w$ Paryżu bawiqcych do Sejmu Wegierskiego, wystosowany przez Komitet — jako wyraz wdzięczności za solidarność narodu węgierskiego z powstaniem listopadowym.

Lelewel miał też w Paryżu do czynienia z założonym późną jesienią 1832 roku Komitetem Emigracji Polskiej pod wodzą bohatera spod Stoczka generała Józefa Dwernickiego ${ }^{68}$. Mickiewicz w liście do Garczyńskiego, przebywającego w Dreznie, z 5 marca 1833 roku pisał o tym, że parę miesięcy wcześniej radził Lelewelowi, aby ten wycofał się z prezesury swego Komitetu i uniknął w ten sposób niepotrzebnych konfliktów, a w konsekwencji wydalenia z Paryża. Chyba zatem poeta czuł się na tyle dojrzałym człowiekiem, iż mógł udzielać rad swojemu dawnemu nauczycielowi. Zwierzał się Garczyńskiemu: „Mówiłem Lelewelowi, żeby zaraz się usunąl: źle to przyjął i teraz widzi, żem dobrze radzi1”69. W kilka miesięcy później, 21 września 1833 roku Lelewel przybył do Brukseli, gdzie spędził resztę życia. Rada,jakiej udzielił Mickiewicz, jak i fakt niewzięcia przezeń udziału w powstaniu listopadowym, czego tak naprawdę Lelewel nigdy do końca, jak przypuszczam, mu nie wybaczył, były przyczynami najprawdopodobniejszymi ochłodzenia się stosunków między nimi na prawie dziesięć lat.

Ostatni list do Lelewela napisał Mickiewicz 22 sierpnia $1842 \mathrm{roku}^{70}$. Poeta jako prezes Wydziału Historycznego Towarzystwa Literackiego Polskiego w Paryżu prosił Lelewela o zorganizowanie w Brukseli grupy polskich emigrantów, którzy pod jego kierownictwem zajęliby się gromadzeniem poloniców historycznych. List pisany był obcą ręką, prawdopodobnie Hipolita Błotnickiego, a jedynie podpisany przez Mickiewicza. Widać, iż zapewne poecie ręka drżała i nie mógł pisać sam do swego danwego mistrza i przyjaciela. Nie wiedział on, jakiej się może spodziewać odpowiedzi po prawie dziesięcioletniej rozłące duchowej. Widać też, jak u dojrzałego mężczyzny język powraca do czasów studenckich. Lelewel znowu stał się dla Mickiewicza "Szanownym mężem” i "JWMościem Panem Dobrodziejem”.

Profesor milczał, poeta zaś ponownie za pośrednictwem Błotnickiego przesłał mu kopię swojego listu. Dopiero wtedy 10 kwietnia 1843 roku, Lelewel odpowiedział odmownie, tłumacząc się wielką ilością zajęć. Było to jego ostatnie pismo wysłane do Mickiewicza. Tė bardzo oficjalne i urzędowe. Mickiewicz został tam nazwany: „Szanownym Ziomkiem” $i$ „szanownym prezesem wydziału”. Lelewel wspomniał o dawniejszych tego typu propozycjach, które odrzucił, dlatego też obecna nie ma sensu. W końcowej partii listu daje on ostatni

\footnotetext{
${ }^{68}$ Ibid., s. 13.

${ }^{69}$ Do Stefana Garczyńskiego, Paryż, 5 III 1833, t. XV, s. 60

${ }^{70}$ Do Joachima Lelewela, Paryz, 22 VIII 1842, t. XV, s. 507.
} 
wykład historii, wskazując na wartość paryskich archiwów i bibliotek publicznych: „Że się znajdują dość ciekawe pamiątki, przytoczę Zygmunta III (...) do gubernatorki Izabelli, w którym wzywając, aby chwytała i wydała mu dwóch konspiratorów, co konspirowali z jakimś podkomorzym, sam Zygmunt III własną ręką w okienkach zostawionych dopisał imiona tych konspiratorów, z których jeden jest Arciszewski. Mówią mi także, że są jakieś tegoż Zygmunta III konszachty z Gustawem Adolfem, etc”71. List kończą „uprzejme i serdeczne pozdrowienia".

W tym miejscu warto zastanowić się nad przyczynami rozejścia się dróg Mickiewicza i Lelewela. Miało ono miejsce już wtedy, gdy poeta nie otrzymał odpowiedzi na swą rozprawę O krytykach i recenzentach warszawskich. Projekt Martyrologii polskiej był Lelewelowi obcy. Religijność Mickiewicza, irracjonalizm i krytycyzm, wreszcie mesjanizm — to powody niechęci Lelewela. On wtedy robił to, co zawsze: milczał. Mickiewicz wolałby może otwarte zarzuty, spór, dyskusję? Obaj zresztą działali politycznie, ale lewicowe myślenie Lelewela było zupełnie odmienne niż Mickiewicza. Jemu stawała się bliska raczej postawa Juliana Ursyna Niemcewicza, a nie ruch wolnościowy Lelewela. Były więc między nimi poważne różnice polityczne i filozoficzne.

Raz jeszcze w swoim życiu Mickiewicz - wykładowca w Collège de France spotkał się w Brukseli z Lelewelem w końcu lipca 1843 roku. Poeta spotkał się później z Towiańskim, a następnie obaj udali się do Szwajcarii, Lelewel doniósł o tym w liście Piotrowi Kopczyńskiemu: „Wczoraj zaszedł do mnie Mickiewicz tu przez Brukselę w dalszą drogę ciągnący”"

O czym rozmawiali dwaj wybitni ludzie?

Zachowała się jedyna skąpa relacja z tego spotkania, którą przesłał do zmartwychwstańców w Paryżu przyjaciel poety — Stefan Witwicki: „Mickiewicz był raz u Lelewela, ale mówił o rzeczach prawie obojętnych, wspomniał tylko, aby duszę trzymać spokojną., lecz prędko zamilkł, gdy mu Lelewel konceptem odparł, że dusza dosyć spokojna, tylko ciało czasem głodne. Rozpowiadał mi to sam Lelewel. (...) Adam powiedział Lelewelowi, że jedzie do Szwajcarii, a może tylko do Strasburga"73.

Od tego czasu dawni przyjaciele oddalili się zupełnie od siebie. Nigdy już więcej nie rozmawiali, ani osobiście, ani listownie.

Z przebiegu tej korespondencji wyłania się obraz innego Mickiewicza, tak różny od tego, jaki znany jest z jego twórczości. Obraz Mickiewicza człowieka, a nie tylko pisarza. Z jednej strony - ucznia, innym zaś razem — równoprawnego partnera swego mistrza, przyjaciela, jednocześnie będącego z nim w konflikcie ideowym.

${ }^{71}$ List Lelewela do Mickiewicza, Paryż, 10 IV 1843, Korespondencja Adama Mickiewicza, t. II, Paryż 1872, s. 207.

${ }^{72}$ List Lelewela do Piotra Kopczyńskiego w Paryżu, Bruksela, 1 VIII 1843, Listy emigracyjne Joachima Lelewela, wydała i wstępem poprzedziła H. Więckowska, t. III: 1842-1848, Kraków 1952, s. 57.

${ }^{73}$ Z. Makowiecka, Kronika życia i twórczości Mickiewvicza: Mickiewicz w Collège de France, X 1840 - V 1844, Warszawa 1968, s. 492 (Witwicki do zmartwychwstańców w Paryżu, 26 VIII 1843, Smolikowski, IV, 133). Ostatnie spotkanie Mickiewicza i Lelewela omawia Górski w swej znakomitej rozprawie, op. cit., s. 20. 